\title{
Proski minnstu fyrirburanna á Íslandi 1988-2012
}

\section{Olga Sigurðardóttir ${ }^{1} æ k n i r$ \\ Kristín Leifsdóttir ${ }^{2,3}$ ææknir \\ Pórður Pórkelsson ${ }^{2,3}$ æeknir \\ Ingibjörg Georgsdóttir ${ }^{4}$ læknir}

${ }^{1}$ Karolinska-sjúkrahúsinu Stokkhólmi, Svípjóð, ${ }^{2}$ Barnaspítala Hringsins

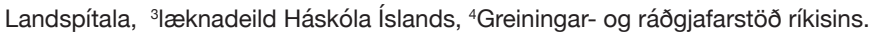

Greinin var unnin við læknadeild Háskóla Íslands, Landspítala og Greiningar- og ráđgjafarstöð ríkisins.

Fyrirspurnum svarar Olga Sigurðardóttir, olgasigridur@gmail.com

\section{Inngangur}

Á síðustu árum og áratugum hafa orðið miklar framfarir í fæðingar- og nýburalækningum sem leitt hafa til betri árangurs í meðhöndlun fyrirbura. Lífslíkur minnstu fyrirburanna (fæðingarpyngd $\leq 1000 \mathrm{~g}$ ) hafa aukist og flestir peirra lifa nú af án alvarlegra fylgikvilla. ${ }^{1,2}$ Fimm ára lifun minnstu fyrirburanna í íslensku býði fór úr 22\% fyrir árabilið 1982-1990 upp í 63\% á árabilinu 20012005. ${ }^{3,4}$ Auk pess er nú hægt að bjarga óproskaðri börnum en áður, allt niður í 22-23 vikna meðgöngulengd., 5 Vanproski barnanna við fæðingu og oft á tíðum mikil veikindi á fyrstu vikum lífs hafa í för með sér aukna hættu á röskun í proska miðtaugakerfis ${ }^{7}$ sem einkum verður vegna skemmda í hvíta efni heilans (periventricular leukomalacia, PVL) eða heilablæðinga. ${ }^{8-11}$ Afleiðingarnar eru margvíslegar. Helst ber að nefna heilalömun (cerebral palsy, CP) og önnur frávik í hreyfiproska ásamt skertum vitsmunaproska, aukna hættu á sjón- og heyrnarskerðingu, námserfiðleika, hegðunarvanda og einhverfurófsröskun.,12-17 Ef litið er á proska minnstu fyrirburanna í heild sinni sýna niðurstöður rannsókna síðustu ára frá Íslandi, Svípjóð og Bretlandi að um tveir priðju barnanna hafa eðlilegan proska eða væg proskafrávik en allt að fimmtungur glímir við alvarlegri proskafrávik. ${ }^{1-4,6,19}$

Oft á tíðum er erfitt að spá fyrir um proska minnstu fyrirburanna og óljóst hvað skilur á milli peirra sem proskast eðlilega og peirra sem gera pað ekki. Markmið pessarar rannsóknar voru að kanna algengi proskafrávika og hamlana meðal minnstu fyrirburanna á Íslandi á 25 ára tímabili og meta hvaða pættir spá fyrir um hömlun hjá pessum börnum.

\section{Á G R I P}

\begin{abstract}
INNGANGUR
Vanproski minnstu fyrirburanna (fæðingarpyngd $\leq 1000 \mathrm{~g}$ ) veldur aukinni hættu á röskun í proska miðtaugakerfis. Afleiðingarnar geta verið skertur hreyfi- og vitsmunaproski, sjón- og heyrnarskerðing, námserfiðleikar, hegðunarvandi og einhverfurófsröskun. Markmið rannsóknarinnar voru að kanna algengi proskafrávika og hömlunar hjá minnstu fyrirburunum á Íslandi á 25 ára tímabili og meta hvaða klínísku pættir spá fyrir um hömlun hjá peim.
\end{abstract}

\section{EFNIVIĐUR OG AĐFERĐIR}

Rannsóknin var afturskyggn og náđi til allra barna sem fæddust á Íslandi 1988-2012, voru $\leq 1000 \mathrm{~g}$ við fæð̌ingu og útskrifuðust á lífi. Rannsóknarhópurinn var sóttur í Vökuskrá Barnaspítala Hringsins. Upplýsingar voru fengnar úr Vökuskrá, sjúkraskrám barnanna og mæðra peirra ásamt gagnagrunni Greiningar- og ráđgjafarstöðvar ríkisins.

\section{NIĐURSTÖĐUR}

Af 189 börnum voru 45 (24\%) með staðfest proskafrávik, 13 (7\%) með væg frávik og 32 (17\%) alvarleg frávik (hömlun) við 3-6 ára aldur. Áhættupættir fyrir hömlun voru fjölburafæđing (ÁH 2,21; 95\% ÖB: 1,19-4,09), Apgar <5 eftir eina mínútu (ÁH 2,40; 95\% ÖB: 1,14-5,07), ef fæðugjöf í sondu hófst meira en fjórum dögum eftir fæððingu (ÁH 2,14; 95\% ÖB: 1,11-4,11), ef fullu fæði var náð eftir meira en 21 dag (ÁH 2,15; 95\% ÖB: 1,11-4,15), lungnabólga á nýburaskeiði (ÁH 3,61; 95\% ÖB: 1,98-6,57) og PVL (ÁH 4,84; 95\% ÖB: 2,81-8,34).

\section{ÁLYKTUN}

Meirihluti minnstu fyrirburanna glímir ekki við alvarleg proskafrávik. Hlutfall barna með hömlun í pessari rannsókn er sambærilegt við niðurstöður annarra íslenskra og erlendra rannsókna en hlutfall vægari proskafrávika í pýðinu er líklega vanmetið. Áhættupættir hömlunar í pessari rannsókn eiga sér hliðstæðu i erlendum rannsóknum.

\section{Efniviður og aðferðir}

Rannsóknin var afturskyggn og náði til allra barna sem fæddust á Íslandi frá 1988 til og með 2012, voru $\leq 1000$ g við fæðingu og útskrifuðust á lífi. Rannsóknarhópurinn var sóttur í gagnagrunn vökudeildar Barnaspítala Hringsins (Vökuskrá). Klínískar upplýsingar voru fengnar úr Vökuskrá og sjúkraskrám barnanna og mæðra peirra (tafla I). 


\begin{tabular}{|c|c|c|c|c|}
\hline $\begin{array}{l}\text { Upplýsingar um mæður og } \\
\text { meðgöngu }\end{array}$ & $\begin{array}{c}\text { Almennar upplýsingar um } \\
\text { börnin }\end{array}$ & $\begin{array}{l}\text { Greiningar barna } \\
\text { á nýburaskeiði }\end{array}$ & $\begin{array}{l}\text { Lyfjagjafir í legu } \\
\text { á vökudeild }\end{array}$ & $\begin{array}{c}\text { Næring, pyngd og } \\
\text { öndunaraðstoð á vökudeild }\end{array}$ \\
\hline \multirow{3}{*}{$\begin{array}{l}\text { Aldur móður } \\
\text { Sjúkdómar á meðgöngu } \\
\text { Lyfjanotkun á meðgöngu } \\
\text { Reykingar á meðgöngu } \\
\text { Gjöf barkstera fyrir fæðingu } \\
\text { Gjöf sýklalyfja fyrir/í fæðingu } \\
\text { Sýkingarmerki í kringum } \\
\text { fæðingu: } \\
\text { Hiti } \\
\text { CRP-gildi } \\
\text { Belghimnabólga }\end{array}$} & \multirow{3}{*}{$\begin{array}{l}\text { Meðgöngulengd } \\
\text { Fæðingarmáti } \\
\text { Kyn } \\
\text { Einburi/fjölburi } \\
\text { Apgar eftir } 1 \text { og } 5 \text { mínútur } \\
\text { Pyngd, lengd og } \\
\text { höfuðummál við fæðingu } \\
\text { Pyngd undir } 10 \text {. hundraðs- } \\
\text { hlutamarki** }^{*}\end{array}$} & \multirow{3}{*}{$\begin{array}{l}\text { Glærhimnusjúkdómur } \\
\text { Lungnabólga } \\
\text { Loftbrjóst } \\
\text { Langvinnur lungnasjúkdómur } \\
\text { Jákvæð blóðræktun } \\
\text { Opin fósturslagrás } \\
\text { Sjónukvilli, gráđa tilgreind } \\
\text { Parmadrepsbólga } \\
\text { Heilablæðing, gráða tilgreind } \\
\text { PVL }\end{array}$} & $\begin{array}{l}\text { Lungnablöðruseyti } \\
\text { Sterar í æð (dexametasón) } \\
\text { Innúðasterar (flútikasón- } \\
\text { própiónat, budesonid) } \\
\text { Prostaglandín-hemlar } \\
\text { (indómetasín, íbúprófen) }\end{array}$ & \multirow{3}{*}{$\begin{array}{l}\text { Aldur pegar fæđingarpyngd } \\
\text { var náð } \\
\text { Aldur pegar fæðugjöf í sondu } \\
\text { hófst } \\
\text { Aldur pegar fullu fæði var náð } \\
\text { CPAP og tími á CPAP } \\
\text { (Hátíðni)-öndunarvél og tími á } \\
\text { öndunarvél }\end{array}$} \\
\hline & & & Aðgerðir í legu á vökudeild & \\
\hline & & & $\begin{array}{l}\text { Opin fósturslagrás } \\
\text { Sjónukvilli } \\
\text { Parmadrepsbólga }\end{array}$ & \\
\hline
\end{tabular}

*Skráð sem vikur og dagar, pannig er meðgöngulengd barns sem fætt var eftir 25 vikna og tveggja daga meðgöngu rituð sem $25^{2}$ vikur. **Ákvarðað út frá fæðingarpyngd, meðgöngulengd og vaxtarferlum fyrir fyrirbura (small for gestational age, SGA). CRP: C-reactive protein

CPAP: Continous positive airway pressure

Leitað var að öllum börnum rannsóknarhópsins í gagnagrunni Greiningar- og ráðgjafarstöðvar ríkisins (GRR) og upplýsingar um börnin sem pangað var vísað voru sóttar í gagnagrunninn í mars 2015. Proskastaða var ákvörðuð út frá nýjustu upplýsingum um proska og færni barns og miðað við ICD-10 greiningarnúmer. Skilgreiningar Alpjóðaheilbrigðisstofnunarinnar (World Health Organization) frá 1980 á skerðingu (impairment), hömlun (disability) og fötlun (handicap) voru hafðar til hliðsjónar pegar matið var gert. ${ }^{20}$

Gagnasöfnun fór fram í Microsoft Excel 2013. Tölfræðiúrvinnsla fór fram í JMP 11 SAS Institute Inc. og 24. útgáfu SPSS. Óparað t-próf og kí-kvaðrat próf voru notuð í samanburði á hópum. Gerð var einpátta og fjölpátta aðhvarfsgreining til að meta áhrif hverrar breytu fyrir sig, í fjölpáttagreiningu var leiðrétt fyrir kyni. Fyrir flokkabreytur voru niðurstöður settar fram sem hlutfallstölur og fyrir talnabreytur voru niðurstöður settar fram sem meðaltöl \pm staðalfrávik. Áhættuhlutfall (ÁH, relative risk) var reiknað með 95\% öryggisbili (ÖB, confidence interval). Tölfræðileg marktækni miðast við p-gildi $<0,05$.

\section{Niðurstöður}

Rannsóknarhópurinn

Á árabilinu 1988 til og með 2012 útskrifuðust 189 fyrirburar með fæðingarpyngd $\leq 1000 \mathrm{~g}$ á lífi af vökudeild Barnaspítala Hringsins, 76 (40\%) drengir og 113 (60\%) stúlkur. 93 börn fæddust á fyrri hluta rannsóknartímabilsins (1988 til og með 2000) og 96 börn á seinni hluta pess (2001 til og með 2012). Mæðraskrár tveggja mæðra fundust ekki. Fæðingarpyngd var að meðaltali 807,4+137,9 g. Меð- göngulengd var að meðaltali $27^{0}$ vikur \pm 13 dagar, $26^{6} \pm 13$ á fyrri hluta tímabilsins og $27^{1} \pm 14$ á pví seinna. Flest börnin fæddust eftir $25^{0}-26^{6}$ vikna og $27^{0}-28^{6}$ vikna meðgöngu eða 73 (39\%) og 64 (33\%). Börn fædd eftir $29^{0}$ vikna meðgöngu eða meira voru 28 (15\%). Einungis 24 börn (13\%) fæddust eftir $23^{0}-24^{6}$ vikna meðgöngu, 8 á fyrri hluta rannsóknartímabilsins og 16 á seinni hluta pess. Af 189 fyrirburum var 61 vísað til mats á Greiningar- og ráðgjafarstöð ríkisins.

\section{Droski minnstu fyrirburanna}

Athuganir á proska barnanna fóru oftast fram við 5-6 ára aldur (mynd 1). Börn með væg proskafrávik ( $n=13$ ) höfðu greiningar á borð við hreyfiproskaraskanir og væg CP-einkenni, málproskaraskanir, vitsmunaproska á tornæmisstigi og sértækar proskaraskanir. Börn með væga hömlun ( $\mathrm{n}=7$ ) voru flest með CP-einkenni. Pau gengu án stuðnings en ekki án erfiðleika og mörg purftu spelkur. Flest voru pau einnig með sértækar proskaraskanir, staðfestar með proskamælingum, en pó ekki á stigi proskahömlunar. Pau börn sem metin voru með alvarlega hömlun $(n=25)$ voru börn með víðtæk frávik í vitsmunaproska, hreyfifærni, sjón og/eða heyrn. Athuganir á vitsmunaproska staðfestu vægar, miðlungs eða alvarlegar proskahamlanir og/eða einhverfu. Einnig voru í peim hópi börn með verulega hamlandi CP-einkenni. Í hópi mikillar hömlunar höfðu öll börnin fleiri en eina greiningu, eitt barn lést á rannsóknartímabilinu vegna afleiðinga fötlunar sinnar, fjögur börn voru með flogaveiki, eitt barn var blint og eitt barn var með kuðungsígræðslu vegna heyrnarleysis. Frekari útlistun á greiningum

\begin{tabular}{|c|c|c|c|c|c|c|c|c|}
\hline & & $\mathrm{CP}$ & Proskahömlun & Proskaraskanir & Einhverfa & Atferlisvandi & Sjónskerðing & Heyrnarskerðing \\
\hline ICD-10 greiningarnúmer & & G80-82 & F70-79 & F80-83/88-89 & F84 & F90/98 & H52-54 & H90-91 \\
\hline Væg hömlun & 7 & 6 & & 6 & 1 & 4 & 1 & \\
\hline Alvarleg hömlun & 25 & 14 & 14 & 17 & 7 & 5 & 7 & 4 \\
\hline Samtals & 32 & 20 & 14 & 23 & 8 & 9 & 8 & 4 \\
\hline Hlutfall af heildinni $(n=189)$ & $17 \%$ & $11 \%$ & $7 \%$ & $12 \%$ & $4 \%$ & $5 \%$ & $4 \%$ & $2 \%$ \\
\hline
\end{tabular}




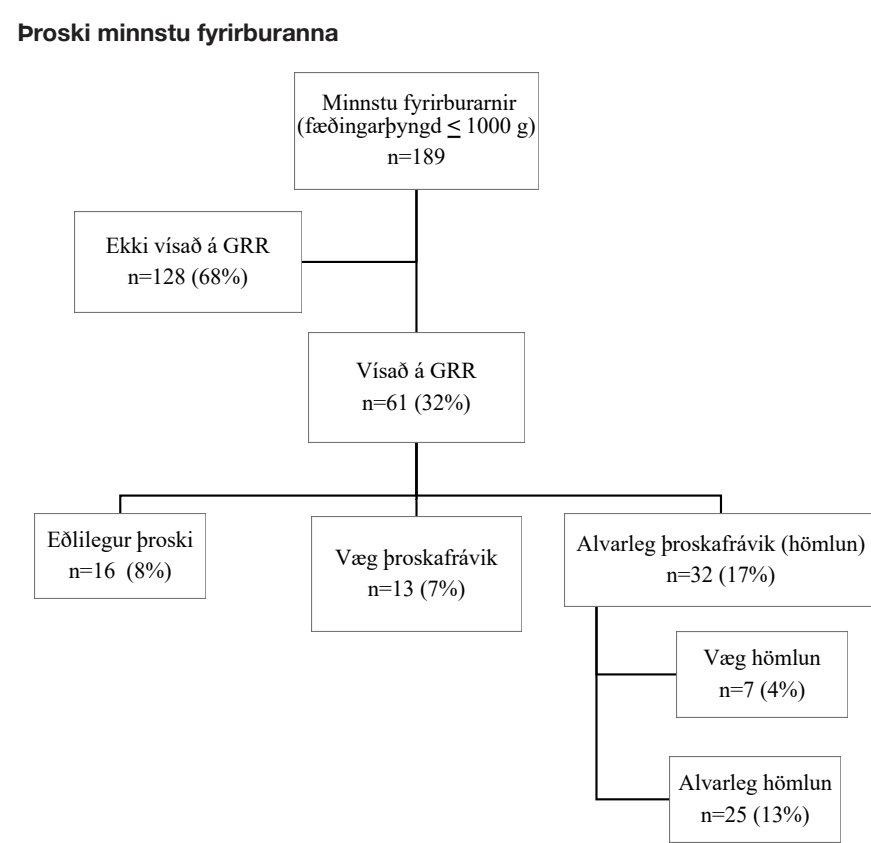

Mynd 1. Yfirlit yfir minnstu fyrirburana á Íslandi 1988-2012. Flæðiritið sýnir rannsóknarhópinn og skiptingu hans með tilliti til mats á GRR og alvarleika proskafrávika. Upplýsingarnar eru settar fram sem fjöldi barna og hlutfall (\%) af heildinni par sem $n=189$.

barna með hömlun má sjá í töflu II. Af peim 32 börnum sem voru með hömlun fæddust 20 (62,5\%) á fyrri hluta rannsóknartímabilsins og 12 (37,5\%) á seinni hluta pess.

\section{Áhættupættir hömlunar}

Rannsóknarhópnum ( $\mathrm{n}=189$ ) var skipt í tvennt, börn með hömlun (n=32) og börn án hömlunar (n=157). Samanburður var gerður á milli pessara tveggja hópa með tilliti til ýmissa breyta sem tengdust meðgöngu, fæðingu og nýburaskeiði barnanna í peim tilgangi að sjá hvort hóparnir væru sambærilegir og til að finna mögulega áhættupætti fyrir hömlun. Leiðrétt var fyrir kyni í samanburðinum. Ekki reyndist marktækur munur á milli hópanna pegar breytur er vörðuðu móður og meðgöngu voru skoðaðar. Niðurstöður einpátta og fjölpátta aðhvarfsgreiningar á öðrum breytum má sjá í töflu III.

Fjölpáttagreining leiddi í ljós 6 áhættupætti fyrir hömlun. Áhættan á hömlun var rúmlega tvöföld fyrir fjölbura samanborið við einbura (ÁH 2,21; 95\% ÖB: 1,19-4,09). Apgar <5 eftir eina mínútu hafði einnig rúmlega tvöfalda áhættu í för með sér samanborið við Apgar $\geq 5$ eftir eina mínútu (ÁH 2,40; 95\% ÖB: 1,14-5,07). Pegar fæðugjöf í sondu hófst meira en fjórum dögum eftir fæðingu var áhættan á hömlun rúmlega helmingi meiri en ef fæðugjöf í sondu hófst við fjögurra daga aldur eða fyrr (ÁH 2,14; 95\% ÖB: 1,11-4,11). Í 90\% tilfella fengu börnin brjóstamjólk í sonduna. Áhættan á hömlun var rúmlega tvöföld hjá börnum sem voru meira en 21 dag að ná fullu fæði samanborið við börn sem voru 20 daga eða skemur að ná fullu fæði (ÁH 2,15; 95\% ÖB: 1,11-4,15). Áhættan á hömlun var rúmlega preföld hjá börnum sem voru greind með lungnabólgu á nýburaskeiði samanborið við önnur börn (ÁH 3,61; 95\% ÖB: 1,98-6,57). Áhættan á hömlun var rúmlega fjórföld hjá börnum með PVL samanborið við önnur börn (ÁH 4,84; 95\% ÖB: 2,81-8,34).

\section{Umræður}

Proski minnstu fyrirburanna

Rannsókn pessi náði til allra barna sem fæddust á Íslandi frá 1988 til og með 2012 með fæðingarpyngd $\leq 1000$ g og útskrifuðust á lífi af vökudeild Barnaspítala Hringsins. Af 189 börnum voru 45 (24\%) með staðfest proskafrávik, 13 (7\%) með væg frávik og 32 (17\%) með alvarleg frávik (hömlun) við 3-6 ára aldur. Stuðst var við pverfaglegt mat á proska og færni barnanna og miðað við ICD10 greiningar en að baki peim liggja greindar- og proskapróf sem framkvæmd voru á GRR. Niðurstöðurnar samrýmast niðurstöðum fyrri íslenskra rannsókna á minnstu fyrirburunum á premur árabilum, 1982-1990, 1991-1995 og 2001-2005 par sem 16\%, 17\% og $19 \%$ voru með staðfesta hömlun við 5 ára aldur. ${ }^{3,4}$ Samanburður við erlendar rannsóknir er erfiðara að meta pví pær nota yfirleitt mismunandi aðferðir til að meta proska og flokka proskafrávik barnanna. Pó má finna hliðstæðar tölur hvað varðar hlutfall alvarlegrar hömlunar í erlendum rannsóknum á borð við sænsku EXPRESS-rannsóknina (börn með fæðingarpyngd <1000 g) og bresku EPICure2-rannsóknina (börn fædd eftir 22-26 vikna meðgöngu). Báðar rannsóknirnar mátu proskastöðu fyrst við tveggja og hálfs árs aldur og sýndu að um fjórðungur hópsins hafði miðlungs til alvarlega hömlun pá, par af $11 \%$ og $13 \%$ alvarlega hömlun, en prír fjórðu proskuðust eðlilega eða höfðu væga hömlun. ${ }^{6,19}$ Hlutfall alvarlegrar hömlunar í pessari rannsókn er einnig 13\%. Fjórðungur hópsins var með staðfest proskafrávik í pessari rannsókn en hlutfall hömlunar í heild sinni var pó lægra auk pess sem hömlun var skipt niður í tvo flokka, væga og alvarlega, ekki prjá líkt og í EXPRESS og EPICure2-rannsóknunum.

Við sex og hálfs árs aldur hafði hlutfall miðlungs til alvarlegrar hömlunar aukist í sænska pýðinu úr fjórðungi í priðjung. Í pessu samhengi er mikilvægt að hafa í huga að yngstu árgangar pessarar rannsóknar voru um tveggja og hálfs árs til 5 ára (börn fædd síðla árs 2009 til og með 2012) pegar leit í gagnagrunni GRR fór fram í mars 2015. Allra alvarlegustu hamlanirnar eru alla jafna komnar fram á peim aldri en vissulega gæti verið að börn úr pessum hópi bættust við hóp hömlunar ef leitað yrði aftur í gagnagrunni GRR í dag. Bið eftir greiningu á GRR er einnig löng en pað er reynsla höfunda að reynt sé að taka fyrirbura inn í forgangi og lenda peir pví síður á biðlista. Afdrif annarra í pessum 128 barna hópi sem ekki var vísað á GRR eru á huldu. Pó má telja ólíklegt að pau glími við meiriháttar vandamál sem valda hömlun. GRR tekur við tilvísunum af öllu Íslandi fyrir börn par sem grunur er um slík vandamál og má pví segja með nokkurri vissu að peim sé vísað pangað fyrr eða síðar. Rannsóknir sýna að nokkuð stór hluti minnstu fyrirburanna er með frávik í proska án hömlunar, til dæmis frávik í hreyfiproska eða væg CP-einkenni, ${ }^{21}$ námserfiðleika, ${ }^{14}$ hegðunarvanda ${ }^{22}$ og raskanir á einhverfurófinu. ${ }^{23}$ Líklegt er pví að hluti pessara 128 barna glími við slík frávik.

Pannig má gera ráð fyrir að pessi rannsókn nái til velflestra peirra sem glíma við meiriháttar vandamál sem leiða til hömlunar, varnagli er pó sleginn hvað varðar yngstu árganga rannsóknarinnar, en vanmeti hlutfall vægari proskafrávika í pýðinu.

Í pessari rannsókn var hlutfall CP 11\% og er pað nokkuð sambærilegt við niðurstöður nýlegra sænskra rannsókna á minnstu fyrirburunum par sem hlutfallið er 9-9,5\%., Рað sama má segja um hlutfall sjón- og heyrnarskerðingar. Samkvæmt samantekt frá 
Tafla III. Samband klíniskra pátta og hömlunar. Samanburðu á minnstu fyrirburunum á íslandi 1988-2012 með og án hömlunar með tilliti til ýmissa klíniskra pátta, leiðrétt fyrir kyni i fjölpáttagreiningunni.

\begin{tabular}{|c|c|c|c|c|}
\hline \multirow{3}{*}{ Klínískir pættir } & \multicolumn{2}{|c|}{ Hömlun } & \multirow[b]{2}{*}{ Einpáttagreining } & \multirow[b]{2}{*}{ Fjölpáttagreining } \\
\hline & Já & Nei & & \\
\hline & $\mathrm{n}=32$ & $\mathrm{n}=157$ & $\mathrm{p}$-gildi & p-gildi \\
\hline Kyn, drengir, $n(\%)$ & $15(47)$ & $61(39)$ & 0,399 & Ómarktækt \\
\hline Meðgöngulengd, meðaltal vikna og daga & $26^{4}$ & $27^{0}$ & 0,425 & Ómarktækt \\
\hline Fæðingarbyngd, meðaltal g & 806 & 808 & 0,948 & Ómarktækt \\
\hline Lengd við fæðingu meðaltal cm & 34 & 34,1 & 0,884 & Ómarktækt \\
\hline Höfuðummál við fæðingu, međaltal cm & 24,2 & 24,1 & 0,983 & Ómarktækt \\
\hline SGA, n (\%) & $6(19)$ & $50(32)$ & 0,139 & Ómarktækt \\
\hline Apgar 1 mín. međaltal & 3,2 & 4,3 & 0,003 & 0,011 \\
\hline Apgar 5 mín. meðaltal & 6,3 & 6,6 & 0,320 & Ómarktækt \\
\hline Fæðing með keisaraskurði, n (\%) & $18(56)$ & $105(67)$ & 0,250 & Ómarktækt \\
\hline Fjölburi, n (\%) & $15(47)$ & $39(25)$ & 0,012 & 0,031 \\
\hline Glærhimnusjúkdómur, n (\%) & $28(88)$ & $114(73)$ & 0,076 & Ómarktækt \\
\hline Gjöf lungnablöðruseytis, $n$ (\%) & $27(84)$ & $108(69)$ & 0,075 & Ómarktækt \\
\hline Lungnabólga, n (\%) & $10(31)$ & $11(7)$ & $<0,001$ & $<0,001$ \\
\hline Loftbrjóst, n (\%) & $2(6)$ & $10(6)$ & 0,980 & Ómarktækt \\
\hline Jákvæð blóðræktun, n (\%) & $11(34)$ & $68(43)$ & 0,350 & Ómarktækt \\
\hline Langvinnur lungnasjúkdómur, n (\%) & $22(71)$ & $89(57)$ & 0,140 & Ómarktækt \\
\hline Sterar í æð, n (\%) & $18(56)$ & $58(37)$ & 0,042 & Ómarktækt \\
\hline Innúðasterar, n (\%) & $15(53)$ & $64(41)$ & 0,523 & Ómarktækt \\
\hline Opin fósturslagrás, n (\%) & $22(69)$ & $85(54)$ & 0,129 & Ómarktækt \\
\hline Prostaglandín hemlar, n (\%) & $18(82)$ & 69 (82) & 0,972 & Ómarktækt \\
\hline Aðgerð v/opinnar fósturslagrásar, n (\%) & $8(36)$ & $18(21)$ & 0,147 & Ómarktækt \\
\hline Sjónukvilli, n (\%) & $11(35)$ & $35(22)$ & 0,118 & Ómarktækt \\
\hline Aðgerð v/sjónukvilla, n (\%) & $2(20)$ & $4(12)$ & 0,505 & Ómarktækt \\
\hline Parmadrepsbólga, n (\%) & $4(13)$ & $6(4)$ & 0,039 & Ómarktækt \\
\hline Aðgerð v/parmadrepsbólgu, n (\%) & $4(100)$ & $4(67)$ & 0,197 & Ómarktækt \\
\hline Heilablæð̌ing, n (\%) & $7(22)$ & $29(19)$ & 0,655 & Ómarktækt \\
\hline Heilablæðing gr. 1 eða 2, n (\%) & $5(16)$ & $26(17)$ & 0,977 & Ómarktækt \\
\hline Heilablæðing gr. 3 eða 4, n (\%) & $2(7)$ & $2(2)$ & 0,078 & Ómarktækt \\
\hline PVL & $12(37)$ & $20(12)$ & $<0,001$ & $<0,001$ \\
\hline Fæđingarbyngd náđ, međaltal aldurs í dögum & 20 & 14 & $<0,001$ & Ómarktækt \\
\hline Upphaf fæðugjafar í sondu, meðaltal aldurs í dögum & 6 & 3 & $<0,025$ & $<0,001$ \\
\hline Aldur pegar fullu fæði var náð, meðaltal aldurs í dögum & 22 & 15 & $<0,004$ & $<0,001$ \\
\hline Öndunarvél, n (\%) & $32(100)$ & $137(87)$ & 0,033 & Ómarktækt \\
\hline Tími á öndunarvél, međaltal daga & 32 & 17 & 0,035 & Ómarktækt \\
\hline CPAP, n (\%) & $19(59)$ & $117(75)$ & 0,082 & Ómarktækt \\
\hline Tími á CPAP, međaltal daga & 31 & 31 & 0,999 & Ómarktækt \\
\hline
\end{tabular}


2016 sést alvarleg sjónskerðing hjá allt að 4,6\% minnstu fyrirburanna og alvarleg heyrnarskerðing hjá allt að 2,5\% peirra. ${ }^{24}$ Í pessari rannsókn var hlutfall sjónskerðingar og heyrnarskerðingar í hópi hömlunar $4 \%$ og $2 \%$. Hlutfall einhverfurófsröskunar (4\%) og hegðunarvanda (5\%) í pessari rannsókn er lægra en í erlendum rannsóknum.13,14 Skýringin á pví kann að vera vanmat rannsóknarinnar á vægari proskafrávikum í pýðinu og ungur aldur yngstu árganganna eins og fyrr segir. Hlutfall proskahömlunar í pessari rannsókn var 7\%. Auk pess voru teknar saman greiningar hinna ýmsu proskaraskana, svo sem málproskaraskana, blandinna sértækra proskaraskana, óyrtra námserfiðleika og proskaraskana á stigi tornæmis (ICD-10 F80-83/88-89). Hlutfall pessara frávika 1 rannsókninni var $12 \%$ og í flestum tilvikum voru petta fylgigreiningar með öðrum hömlunargreiningum.

Af peim 32 börnum sem voru með hömlun fæddust 20 á fyrri hluta rannsóknartímabilsins (1988-2000) og 12 á seinni hluta pess (2001-2012) . Hlutfall peirra barna sem fæddust eftir 23-24 vikna meðgöngu jókst á milli pessara tveggja tímabila, eða úr 9\% fæðinga á fyrri hluta tímabilsins upp í 17\% fæðinga á seinni hluta tímabilsins. Í ljósi pessa má draga pá ályktun að prátt fyrir að börnin fæðist minni og óproskaðri en áður virðist hlutfall hömlunar ekki aukast. Petta endurspeglar trúlega pær framfarir sem orðið hafa í meðferð minnstu fyrirburanna á peim 25 árum sem rannsóknartímabilið spannar.

\section{Áhættupættir hömlunar}

Í pessari rannsókn var áhættan á hömlun rúmlega tvisvar sinnum meiri hjá fjölburum en einburum. Fyrri rannsóknir hafa ekki verið á einu máli hvað petta varðar og spurning hvort sama niðurstaða hefði fengist ef leiðrétt hefði verið fyrir meðgöngulengd. Í rannsókn Källén og félaga á áhrifum fæðingapátta (obstetric factors) á afdrif minnstu fyrirburanna var fjölburafæðing áhættupáttur fyrir dauða á fyrsta sólarhring lífs en ekki áhættupáttur fyrir hömlun við tveggja og hálfs árs leiðréttan aldur. ${ }^{25}$ Í rannsókn Camp og félaga á áhættupáttum proskahömlunar í hópi tæplega 36.000 barna sem voru hluti af The Collaborative Perinatal Project var fjölburafæðing áhættupáttur fyrir proskahömlun við 7 ára aldur. ${ }^{26}$

Áhættan á hömlun var rúmlega tvöföld fyrir Apgar <5 eftir eina mínútu samanborið við Apgar $\geq 5$ eftir eina mínútu. Margar rannsóknir benda til pess sama, pað er að lágur Apgar eftir eina og/eða 5 mínútur tengist aukinni hættu á hömlun, par á meðal CP og skertum vitsmunaproska bæði í hópi fyrirbura og fullbura. ${ }^{25-29}$

Í pessari rannsókn voru tveir áhættupættir hömlunar sem tengdust fæðugjöf minnstu fyrirburanna. Annars vegar tvöföld áhætta pegar fæðugjöf um meltingarveg hófst meira en fjórum dögum eftir fæðingu og hins vegar pegar fullu fæði var náð eftir meira en priggja vikna aldur. Í flestum tilfellum fengu börnin brjóstamjólk í sonduna en pað er kjörfæða fyrir nýbura. ${ }^{30,31}$ Líklegast er hér ekki um raunverulega áhættupætti að ræða heldur breytur sem endurspegla að börn með hömlun hafi verið veikari eftir fæðingu en börn án hömlunar. Rétt og nægjanleg næring er nauðsynleg fyrir vöxt minnstu fyrirburanna. ${ }^{32-34}$ Rannsóknir hafa sýnt að ásættanlegur vöxtur hefur jákvæð áhrif á taugaproska og pví hægari sem vöxturinn er eftir fæðingu pví meiri hætta er á röskun í proska miðtaugakerfis. ${ }^{35-38}$ Í dag er mælt með að hefja fæðugjöf um meltingarveg sem fyrst, helst á fyrsta sólarhring lífs. ${ }^{39}$ Annar langsóttari möguleiki er pví að pessir pættir endurspegli að einhverju leyti mikilvægi næringar fyrir taugaproska barnanna en um slíkt er ekki unnt að álykta pegar engin gögn liggja fyrir um vöxt barnanna.

Áhættan á hömlun í pessari rannsókn var rúmlega preföld fyrir börn sem greind voru með lungnabólgu á nýburaskeiði samanbor¡ð við önnur börn. Trúlega er hér einnig um að ræða breytu sem endurspeglar veikari börn í hópi hömlunar. Hátt hlutfall barna í hópi hömlunar, eða priðjungur, fékk pessa greiningu sem í dag er sjaldséð á nýburagjörgæslum. Hugsanlega hefur greiningin í einhverjum tilvikum verið sett pegar börn voru með einkenni sýkingar en neikvæða blóðræktun (sepsis without positive blood culture). Pá hefur lungnabólga sannarlega verið algengari áður fyrr pegar öndunarvélameðferð var lengri og má finna vísbendingar um petta í niðurstöðunum: Meðaltími öndunarvélameðferðar var næstum pví tvöfalt lengri hjá börnum með hömlun (32 dagar) en án hömlunar (17 dagar), pó ekki marktækur munur, og 15 af 21 lungnabólgutilfelli rannsóknarinnar voru á fyrri hluta rannsóknartímabilsins. Sýkingar og pá sér í lagi staðfest sýklasótt (sepsis with positive blood culture) hefur verið tengd aukinni áhættu á proskafrávikum síðar meir. ${ }^{40-42}$ Í pessari rannsókn reyndist hins vegar ekki munur á tíðni jákvæðra blóðræktana hjá börnum með og án hömlunar. Petta kann að skýrast af litlu úrtaki og pýði sem og gloppum í gögnunum.

PVL var áhættupáttur fyrir hömlun líkt og sýnt hefur verið fram á í erlendum rannsóknum. ${ }^{11,43,44}$ Aftur á móti reyndist ekki marktækt samband vera á milli heilablæðinga og hömlunar en alvarleg heilablæðing er vel pekktur áhættupáttur fyrir hömlun, sérstaklega $\mathrm{CP}$ og proskahömlun. ${ }^{8-10}$ Athygli vekur einnig lág tíðni alvarlegra heilablæðinga í pýðinu samanborið við erlendar tíðnitölur ${ }^{45-47}$ en ómskoðun var gerð á nánast öllum börnum rannsóknarinnar, ýmist af röntgen- eða nýburalækni, á einhverjum tímapunkti. Sennilega væri tíðnin hærri ef börn sem létust fyrir útskrift af vökudeild hefðu verið með í rannsókninni. Einnig má vera að gráđa heilablæðinganna hafi í einstaka tilfellum verið vanmetin pegar gagnasöfnun fór fram. Pá var ekki heldur marktækt samband á milli meðgöngulengdar og hömlunar, nokkuð sem rannsóknir sýna með óyggjandi hætti að hefur forspárgildi fyrir hömlun og eykstáhættan í öfugu hlutfalli við meðgöngulengd. 2,6,10,11 Lítið úrtak og pýði kann að skýra af hverju alvarlegar heilablæðingar og meðgöngulengd voru ekki áhættupættir hömlunar og ef til vill hefði munurinn verið meiri ef rannsóknarhópurinn hefði verið stærri og tölfræðilegt afl meira. Höfundar veltu pví fyrir sér hvort skýringin á litlum mun á meðgöngulengd gæti legið í lengd rannsóknartímabilsins og peim breytingum sem orðið hafa á hópnum á pessu 25 ára tímabili. Pegar meðgöngulengd hópsins var hins vegar skoðuð yfir tímabilið kom í ljós að hún breyttist sáralítið.

\section{Styrkleikar og takmarkanir rannsóknar}

Helstu styrkleikar pessarar rannsóknar er að hún rannsakar pýði heillar pjóðar á einum stað - vökudeild Barnaspítala Hringsins, einu nýburagjörgæslunni á Íslandi. Mat á proska barnanna fór auk pess fram á einum stað, Greiningar- og ráðgjafarstöð ríkisins. Við 
matið var ekki einungis stuðst við greiningar með ICD-10 númerum heldur var færnimat einnig haft til hliðsjónar og reynt að meta lífsgæði barnanna með tilliti til proska og hamlana.

Í afturskyggnri rannsókn sem pessari er óhjákvæmilegt að upplýsingaöflun úr sjúkraskrám sé ófullkomin. Skráningu upplýsinga í sjúkraskrár var oft á tíðum ábótavant og ósamræmi í skráningu upplýsinga torveldaði gagnasöfnun. Önnur takmörkun er mat á proska yngstu árganga rannsóknarinnar, hvers aldur var allt niður í um tveggja og hálfs árs pegar proskastaða hópsins var metin í mars 2015.

\section{Lokaoro}

Stór hluti minnstu fyrirburanna proskast eðlilega en vandamál peirra sem ekki gera pað eru oft á tíðum margpætt og sérhæfð. Skipulagt fyrirburaeftirlit hefur verið starfrækt á Barnaspítala Hringsins í núverandi mynd frá árinu 2012. Eftirlitið fylgir minnstu fyrirburunum markvisst eftir fram til 6 ára aldurs. Um er að ræða pverfaglegt teymi sem samanstendur af læknum, hjúkrunarfræðingum, sjúkrapjálfurum, talmeinafræðingi, næringarfræðingi, sálfræðingum og félagsráðgjafa auk pess sem náið samstarf er við Greiningar- og ráðgjafarstöð ríkisins, Heyrnarog talmeinastöð Íslands og Pjónustu- og pekkingarmiðstöð fyrir blinda og sjónskerta. Fyrirburaeftirlitið veitir börnunum og fjölskyldum peirra stuðning og stuðlar að bættum proska og velferð barnanna. Með eftirlitinu verða auk pess til yfirgripsmiklar upplýsingar um proska minnstu fyrirburanna á Íslandi sem gefa einstakt tækifæri til frekari rannsókna á pessu sviði.

\section{Pakkir}

Sérlegar pakkir fá Edda Björk Pórðardóttir fyrir tölfræðilega útreikninga og Bríet Einarsdóttir fyrir aðstoð við gagnaöflun. Rannsóknin var styrkt af Vísindasjóði Landspítala.

\section{Outcome of Extremely Low Birth Weight Children in Iceland 1988-2012}

\author{
Olga Sigurðardóttir \\ Kristín Leifsdóttir ${ }^{2,3}$ \\ Pórður Pórkelsson ${ }^{2,3}$ \\ Ingibjörg Georgsdóttir ${ }^{4}$
}

Introduction: Extremely low birth weight (ELBW) children (birth weight $\leq 1000 \mathrm{~g}$ ) are at risk of adverse neurodevelopmental outcome. The objectives of this study were to determine the prevalence of developmental disorders and disabilities among ELBW children born in Iceland during a 25 year period and to assess which clinical factors predict disability among these children.

Material and methods: A retrospective study of all ELBW children born in Iceland 1988-2012 and discharged alive. The study group was found in the Children's Hospital of Iceland NICU registry. Information was gathered from the NICU registry, the children's and their mothers' medical records and the State Diagnostic and Counselling Centre database.

Results: Of 189 children 45 (24\%) had developmental disorders, 13
(7\%) had mild disorders and 32 (17\%) had major disorders (disability) at 3-6 years. Risk factors for disability were multiple birth (RR 2.21; 95\% Cl: 1.19-4.09), Apgar < 5 after one minute (RR 2.40; 95\% Cl: 1.14-5.07), the initiation of enteral feeding more than four days after birth (RR 2.14; 95\% Cl: 1.11-4.11), full enteral feeding achieved after more then 21 days (RR 2.15; 95\% Cl: 1.11-4.15), neonatal pneumonia (RR $3.61 ; 95 \% \mathrm{Cl}$ : 1.98-6.57) and PVL (RR 4.84; $95 \% \mathrm{Cl}$ : 2.81-8.34).

Conclusion: The majority of ELBW children do not have major developmental disorders. The rate of disability in this study is similar to other studies. The study probably underestimates the rate of mild developmental disorders in the Icelandic population. Risk factors for disability in this study are comparable to previous studies.

'Karolinska University Hospital, ${ }^{2}$ Children's Hospital of Iceland, Landspitali University Hospital, ${ }^{3}$ Faculty of Medicine, University of Iceland,

${ }^{4}$ The State Diagnostic and Counselling Centre.

Key words: extremely low birth weight, preterm, neurodevelopment, outcome.

Correspondence: Olga Sigurðardóttir, olgasigridur@gmail.com 


\section{Heimildir}

1. Serenius F, Ewald U, Farooqi A, Fellman V, Hafström M, Hellgren K, et al. Neurodevelopmental Outcomes Among Extremely Preterm Infants 6.5 Years After Active Perinatal Care in Sweden. JAMA Pediatr 2016; 170: 954.

2. Holsti A, Adamsson M, Serenius F. Two-thirds of adolescents who received active perinatal care after extremely preterm birth had mild or no disabilities. Acta Paediatr 2016; 105: 1288-97.

3. Georgsdóttir I, Dagbjartsson A. Litlir fyrirburar á Íslandi. Lífslíkur og fötlun. Læknablaðið 2003; 89: 299-302.

4. Jonsdottir GM, Georgsdottir I, Haraldsson A Hardardottir H, Thorkelsson T, Dagbjartsson A. Survival and neurodevelopmental outcome of ELBW children at 5 years of age: Comparison of two cohorts born 10 years apart. Acta Paediatr 2012; 101: 714-8.

5. García-Muñoz Rodrigo F, Díez Recinos AL, García-Alix Pérez A, Figueras Aloy J, Vento Torres M. Changes in Perinatal Care and Outcomes in Newborns at the Limit of Viability in Spain: The EPI-SEN Study. Neonatology 2015; 107: 120-9.

6. Serenius F, Källén $K$, Blennow M, Ewald U, Fellman V, Holmström G, et al. Neurodevelopmental Outcome in Extremely Preterm Infants at 2.5 Years After Active Perinatal Care in Sweden. JAMA 2013; 309: 1810-20.

7. Stoll BJ, Hansen NI, Bell EF, Shankaran S, Laptook AR, Walsh MC, et al. Neonatal outcomes of extremely preterm infants from the NICHD Neonatal Research Network. Pediatrics 2010; 126: 443-56.

8. Volpe JJ. Brain injury in premature infants: a complex amalgam of destructive and developmental disturbances. Lancet Neurol 2009; 8: 110-24.

9. Mukerji A, Shah V, Shah PS. Periventricular/ Intraventricular Hemorrhage and Neurodevelopmental Outcomes: A Meta-analysis. Pediatrics 2015; 136: 1132-43.

10. Tsai AJ, Lasky RE, John SD, Evans PW, Kennedy KA. Predictors of neurodevelopmental outcomes in preterm infants with intraparenchymal hemorrhage. J Perinato 2014; 34: 399-404.

11. Woodward LJ, Clark CAC, Bora S, Inder TE. Neonatal White Matter Abnormalities an Important Predictor of Neurocognitive Outcome for Very Preterm Children. Baud O, ed. PLoS One 2012; 7: e51879.

12. Lindström K, Lindblad F, Hjern A. Preterm birth and attention-deficit/hyperactivity disorder in schoolchildren. Pediatrics 2011; 127: 858-65.

13. Johnson S, Hollis C, Kochhar P, Hennessy E, Wolke D Marlow N. Autism Spectrum Disorders in Extremely Preterm Children. J Pediatr 2010; 156: 525-31.e2.

14. Farooqi A, Adamsson M, Serenius F, Hägglöf B. Executive functioning and learning skills of adolescent children born at fewer than 26 weeks of gestation. PLoS One 2016; 11 : e0151819.

15. Hutchinson E a, De Luca CR, Doyle LW, Roberts G, Anderson PJ. School-age Outcomes of Extremely Preterm or Extremely Low Birth Weight Children. Pediatrics 2013 131: e1053-e1061.

16. Rahi JS, Cable N. Severe visual impairment and blindness in children in the UK. Lancet 2003; 362: 1359-65.

17. Doyle LW, Roberts G, Anderson PJ. Outcomes at Age 2 Years of Infants < 28 Weeks' Gestational Age Born in Victoria in 2005. J Pediatr 2010; 156: 49-53.e1.

18. Marret S, Marchand-Martin L, Picaud J-C, Hascoët J-M, Arnaud C, Rozé J-C et al. Brain injury in very preterm children and neurosensory and cognitive disabilitie during childhood: the EPIPAGE cohort study. PLoS One 2013; 8: e62683.
19. Moore T, Hennessy EM, Myles J, Johnson SJ, Draper ES, Costeloe KL, et al. Neurological and developmental outcome in extremely preterm children born in England in 1995 and 2006: the EPICure studies. BMJ 2012; 345: e7961.

20. World Health Organization. International Classification of Impairments, Disabilites and Handicaps. 1980

21. Arnaud C, Daubisse-Marliac L, White-Koning M, Pierrat V, Larroque B, Grandjean $\mathrm{H}$ et al. Prevalence and Associated Factors of Minor Neuromotor Dysfunctions at Age 5 Years in Prematurely Born Children. Arch Pediatr Adolesc Med 2007; 161: 1053

22. Farooqi A, Hägglöf B, Serenius F. Behaviours related to executive functions and learning skills at 11 years of age after extremely preterm birth: a Swedish national prospective follow-up study. Acta Paediatr 2013; 102: 625-34.

23. Johnson S, Hollis C, Kochhar P HE, Wolke D MN Psychiatric Disorders in Extremely Preterm Children: Longitudinal Finding at Age. JAAC 2017; 49: 453-463. e1.

24. Rogers EE, Hintz SR. Early neurodevelopmental outcomes of extremely preterm infants. Semin Perinatol 2016; 40: 497-509.

25. Källén K, Serenius F, Westgren M, Maršál K. Impact of obstetric factors on outcome of extremely preterm births in Sweden: Prospective population-based observational study (EXPRESS). Acta Obstet Gynecol Scand 2015; 94 . 1203-14.

26. Camp BW, Broman SH, Nichols PL, Leff M. Maternal and neonatal risk factors for mental retardation: Defining the "at-risk" child. Early Hum Dev 1998; 50: 159-73.

27. Lie KK, Grøholt EK, Eskild A. Association of cerebral palsy with Apgar score in low and normal birthweight infants: Population based cohort study. BMJ 2010; 341: 817

28. Moster D, Lie RT, Irgens LM, Bjerkedal T, Markestad T. The association of Apgar score with subsequent death and cerebral palsy: A population-based study in term infants. J Pediatr 2001; 138: 798-803.

29. Ehrenstein V. Association of Apgar scores with death and neurologic disability. Clin Epidemiol 2009; 1: 45-53.

30. Victoria CG, Bahl R, Barros AJD, Franca GVA, Horton $\mathrm{S}$, Krasevec J, et al. Breastfeeding in the 21st century: epidemiology, mechanisms, and lifelong effect. Lancet 2016; 387: 475-90.

31. Rollins NC, Bhandari N, Hajeebhoy N, Horton S, Lutter CK, Martines JC, et al. Why invest, and what it will take to improve breastfeeding practices. Lancet 2016; 387: 491504

32. Dinerstein A, Nieto RM, Solana CL, Perez GP, Otheguy LE, Larguia AM. Early and aggressive nutritional strategy (parenteral and enteral) decreases postnatal growth failure in very low birth weight infants. J Perinatol 2006; 26: 436-42.

33. Maggio L, Cota F, Gallini F, Lauriola V, Zecca C, Romagnoli C. Effects of high versus standard early protein intake on growth of extremely low birth weight infants. J Pediatr Gastroenterol Nutr 2007; 44: 124-9.

34. Cormack BE, Bloomfield $\mathrm{FH}$. Increased protein intake decreases postnatal growth faltering in ELBW babies. Arch Dis Child Fetal Neonatal Ed 2013; 98: F399-404.

35. Ehrenkranz RA, Dusick AM, Vohr BR, Wright LL, Wrage LA, Poole WK. Growth in the neonatal intensive care unit influences neurodevelopmental and growth outcomes of extremely low birth weight infants. Pediatrics 2006; 117: 1253-61.
36. De Jesus LC, Pappas A, Shankaran S, Li L, Das A, Bell EF, et al. Outcomes of small for gestational age infants born at $<27$ weeks' gestation. J Pediatr 2013; 163: 55-60. e1-3.

37. Ramel SE, Demerath EW, Gray HL, Younge N, Boys C, Georgieff MK. The relationship of poor linear growth velocity with neonatal illness and two-year neurodevelopment in preterm infants. Neonatology 2012; 102: 19-24.

38. Franz AR, Pohlandt F, Bode H, Mihatsch WA, Sander $\mathrm{S}$, Kron $\mathrm{M}$, et al. Intrauterine, Early Neonatal, and Postdischarge Growth and Neurodevelopmental Outcome at 5.4 Years in Extremely Preterm Infants After Intensive Neonatal Nutritional Support. Pediatrics 2009; 123: e101.

39. Dutta S, Singh B, Chessell L, Wilson J, Janes M, McDonald $\mathrm{K}$, et al. Guidelines for feeding very low birthweight infants. Nutrients 2015; 7: 423-42.

40. Schlapbach LJ, Aebischer M, Adams M, Natalucci G, Bonhoeffer J, Latzin P et al. Impact of sepsis on neurodevelopmental outcome in a Swiss National Cohort of extremely premature infants. Pediatrics 2011; 128 : e34857.

41. Shah DK, Doyle LW, Anderson PJ, Bear M, Daley AJ, Hunt RW, et al. Adverse Neurodevelopment in Preterm Infants with Postnatal Sepsis or Necrotizing Enterocolitis is Mediated by White Matter Abnormalities on Magnetic Resonance Imaging at Term. J Pediatr 2008; 153: 170-5.

42. Bassler D, Stoll BJ, Schmidt B, Asztalos EV, Roberts RS, Robertson CMT, et al. Using a Count of Neonatal Morbidities to Predict Poor Outcome in Extremely Low Birth Weight Infants: Added Role of Neonatal Infection. Pediatrics 2009; 123: 313-8.

43. Iwata S, Nakamura T, Hizume E, Kihara H, Takashima S, Matsuishi T, et al. Qualitative Brain MRI at Term and Cognitive Outcomes at 9 Years After Very Preterm Birth. Pediatrics 2012; 129: e1138-47.

44. Spittle AJ, Cheong J, Doyle LW, Roberts G, Lee KJ, Lim J, et al. Neonatal white matter abnormality predicts childhood motor impairment in very preterm children. Dev Med Child Neurol 2011; 53: 1000-6.

45. EXPRESS Group. Incidence of and risk factors for neonatal morbidity after active perinatal care: extremely preterm infants study in Sweden (EXPRESS). Acta Paediatr 2010; 99: 978-92.

46. Bolisetty S, Dhawan A, Abdel-Latif M, Bajuk B, Stack J, Lui K. Intraventricular Hemorrhage and Neurodevelopmental Outcomes in Extreme Preterm Infants. Pediatrics 2014; 133: 55-62.

47. Groenendaal F, Termote JU, van der Heide-Jalving M, van Haastert IC, de Vries LS. Complications affecting preterm neonates from 1991 to 2006: what have we gained? Acta Paediatr 2010; 99: 354-8.

Greinin barst til blaðsins 6. september, sampykkt til birtingar 21. janúar 2020. 